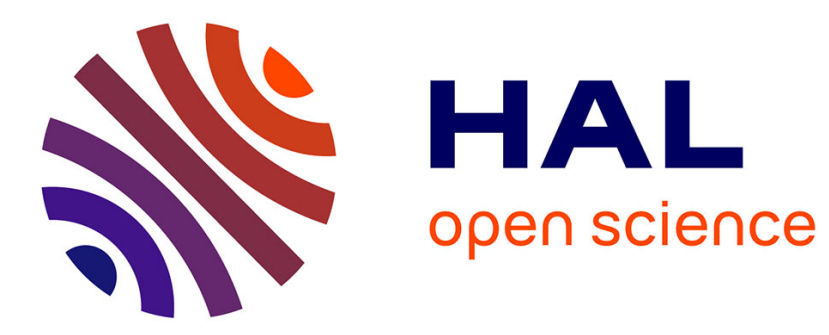

\title{
Sap flow measurements of Ceriops tagal and Rhizophora mucronata mangrove trees by deuterium tracing and lysimetry
}

Luc Lambs, Anaïs Saenger

\section{- To cite this version:}

Luc Lambs, Anaïs Saenger. Sap flow measurements of Ceriops tagal and Rhizophora mucronata mangrove trees by deuterium tracing and lysimetry. Rapid Communications in Mass Spectrometry, 2011, 25 (19), pp.2741-2748. 10.1002/rcm.5098 . hal-01335894

\author{
HAL Id: hal-01335894 \\ https://hal.science/hal-01335894
}

Submitted on 22 Jun 2016

HAL is a multi-disciplinary open access archive for the deposit and dissemination of scientific research documents, whether they are published or not. The documents may come from teaching and research institutions in France or abroad, or from public or private research centers.
L'archive ouverte pluridisciplinaire HAL, est destinée au dépôt et à la diffusion de documents scientifiques de niveau recherche, publiés ou non, émanant des établissements d'enseignement et de recherche français ou étrangers, des laboratoires publics ou privés. 


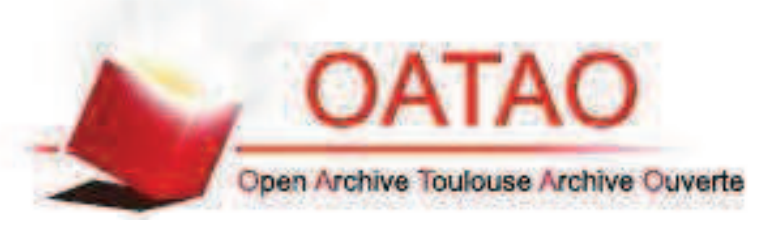

\section{Open Archive TOULOUSE Archive Ouverte (OATAO)}

OATAO is an open access repository that collects the work of Toulouse researchers and makes it freely available over the web where possible.

This is an author-deposited version published in : http://oatao.univ-toulouse.fr/ Eprints ID : 11074

To link to this article : DOI : $10.1002 / \mathrm{rcm} .5098$

URL : http://dx.doi.org/10.1002/rcm.5098

To cite this version : Lambs, Luc and Saenger, Anaïs Sap flow measurements of Ceriops tagal and Rhizophora mucronata mangrove trees by deuterium tracing and lysimetry. (2011) Rapid Communications in Mass Spectrometry, vol. 25 ( $\left.\mathrm{n}^{\circ} 19\right)$. pp. 27412748. ISSN $\underline{0951-4198}$

Any correspondance concerning this service should be sent to the repository administrator: staff-oatao@,listes-diff.inp-toulouse.fr 


\title{
Sap flow measurements of Ceriops tagal and Rhizophora mucronata mangrove trees by deuterium tracing and lysimetry ${ }^{\dagger}$
}

\author{
Luc Lambs ${ }^{1 *}$ and Anaïs Saenger ${ }^{1,2}$ \\ ${ }^{1}$ Ecolab, UMR 5245 CNRS-UPS-INPT, bat 4R1, 118 route de Narbonne, 31062 Toulouse, Cedex 9, France \\ ${ }^{2}$ Cemagref, UR Mountain Ecosystems, 38402 Saint-Martin-d'Hères, France
}

\begin{abstract}
Mangrove forest trees grow in severe conditions such as diurnal submersion and high salinity surface and subsurface waters. This study focuses on two species on Mayotte Island, i.e. Ceriops tagal and Rhizophora mucronata, living in the middle range of the coastal mangrove. The seedlings of these trees were planted in a tropical greenhouse with an original pump system built to reproduce the natural tidal effect. The water used by these saplings, in two contrasted salinity conditions, was measured by lysimetry. For adult species, the trees' water consumption was measured on the field side after being injected with heavy water $\left(\mathrm{D}_{2} \mathrm{O}\right)$. Our work shows that this isotopic technique also works in saline conditions, and a water consumption of around $1 \pm 0.2 \mathrm{~L}$ per day and per centimeter of diameter was found. These values are discussed as follows: the techniques used, the distinctive features of the mangrove trees, and other factors affecting the water absorption.
\end{abstract}

\begin{abstract}
Mangroves forests are special ecosystems that grow in the intertidal zone of tropical and subtropical latitudes. Species are subjected to extreme conditions such as diurnal inundations, periods of desiccation and high salinity of surface and subsurface water. The way in which these trees use water in this constrained environment is a key process for understanding the functional traits of mangroves and for local water resource management. ${ }^{[1]}$ Surprisingly, very few measurements have been made at tree or stand levels and whether the transpiration rate of mangrove trees is low or high remains an open question. ${ }^{[2-4]}$

Without the possibility of direct measurements, the widespread view was that mangrove plants had low transpiration rates and stomatal conductance due to high salt levels in their environment. ${ }^{[5-7]}$ In mangrove substrates, the considerable negative water potential tends to extract water from root tissues. Since the availability of water was very low, trees have been considered as 'physiological xerophytes'. ${ }^{2]}$ Saenger ${ }^{[8]}$ points out that the leaves of mangrove trees exhibit a range of xeromorphic features although he acknowledges that their water conservation function remains controversial.

From another point of view, high transpiration rates can be expected from the high sun exposure and the continual availability of water in the mangrove environment, given that trees have mechanisms to take up water despite the strong osmotic potentials. ${ }^{[9,10]}$ However, numerous authors have
\end{abstract}

\footnotetext{
* Correspondence to: L. Lambs, Ecolab, UMR 5245 CNRS-UPSINPT, bat 4R1, 118 route de Narbonne, 31062 Toulouse Cedex 9, France.

E-mail: lambs@cict.fr; luclambs@orange.fr

+ Presented at the 6th Congress of the French Society of Stable Isotopes (Société Française des Isotopes Stables, SFIS) held 26-29 October 2010 in Toulouse, France.
}

shown that mangroves are salt tolerant only within certain limits ${ }^{[2]}$ and that they are more likely to use the lower salinity water as freshwater lenses or surface water reduced in salinity by rainfall. ${ }^{[1-14]}$ Mangroves are thus referred to as "facultative halophytes": while they tolerate salt water, it is not essential for their survival. ${ }^{[2]}$

Hence, the transpiration rate in mangroves appears to be highly variable and a function of the local salinity. ${ }^{[8,15,16]}$ This means that water use in a stand must be determined while considering the season, the meteorological conditions and the local hydrology. ${ }^{[1]}$

The challenge is to find methods for measuring sap flow rates taking into account this high temporal and spatial variability in the mangrove habitat. Until now, the majority of studies have used indirect ways to calculate sap flow or methods that did not involve fluctuating conditions of the mangrove stand. Apart from the physiological approach at leaf or shoot level (net photosynthesis and stomatal conductance), only two groups of methods exist to provide quantitative estimates of whole-tree water use. The most employed methods are heat balance, heat pulse or heat dissipation using the heat as a tracer for sap movement. The second group of techniques involves radioisotopes or stable isotope tracers such as deuterium $\left(\mathrm{D}_{2} \mathrm{O}\right)$ tracing developed by Calder et al. ${ }^{[17-19]}$

This latter technique provides the advantages of integrating the properties of a large portion of the tree vascular system over time, thus revealing much information about the sap velocity, whole tree water flux and water residence time. ${ }^{[18-21]}$ Moreover, stable isotope (deuterium) tracing requires less sophisticated equipment than heat tracing and it is rapid and easy to perform. This method have been used successfully in the field on beech trees, ${ }^{[20]}$ on coniferous species, ${ }^{[21]}$ and recently on tropical trees. ${ }^{[22]}$ This method was selected in our study since it seemed well suited to our research site in Mayotte which is flooded twice a day. This is the first attempt to use this technique in mangrove species. 
The objectives of this study were (1) to test the application of the deuterium tracing method for the estimation of the whole-tree water use of mangroves species; (2) to compare the difference in the sap flow and sap velocity of the two principal mangrove trees in Mayotte Island (Comoros Archipelago, Indian Ocean), i.e. Ceriops tagal and Rhizophora mucronata; and (3) to evaluate the growth and the water-use response of the two species to salinity.

\section{EXPERIMENTAL}

\section{Experimental layout in tropical greenhouse (Toulouse, France)}

Twelve 1-year-old seedlings of Rhizophora mucronata (Lam.) and twelve of Ceriops tagal (Perr.), raised in low salinity, were planted in individual pots in a sandy-clay substrate $(20 \%$ horticultural sand, $15 \%$ clay and $65 \%$ compost) in January 2008 (Table 1).

The pots, whose bottoms allowed drainage, were placed in groups of six in small tanks filled with water on a $3 \mathrm{~cm}$ thick grate. An original homemade programmed system was designed with water pumps, a water level detector and four water tanks. This system directs the water from one tank to the next, every $6 \mathrm{~h}$, imitating the natural tide cycle. To test the effect of salinity on sapling water used and growth, two tanks were adjusted to sea concentrations $(600 \mathrm{mmol} \mathrm{NaCl} / \mathrm{L}$, $35 \%$ ), while the other two tanks were maintained at low salinity $(60 \mathrm{mmol} \mathrm{NaCl} / \mathrm{L}, 3.5 \%$ o).

The water consumption was measured by lysimetry three times: 2 months (3 March, 2008), 3 months (4 April, 2008) and 4 months (5 June, 2008) after placement in their respective salinities. For this purpose, a double plastic bag was placed in order to surround and isolate the bases of the pots.

The weight variation of each of the 24 small saplings was measured over $24 \mathrm{~h}$. Concurrently with these measurements, we tested the application of the deuterium tracing technique on mangrove before its use in the field. Deuterated water $\left(\mathrm{D}_{2} \mathrm{O}, 0.5 \mathrm{~mL}, 99.85 \%\right.$; Euriso-top, Saclay, Gif sur Yvette, France) was injected into the eight bigger Rhizophora propagules using a $2 \mathrm{~mL}$ syringe. The diameters of the Ceriops propagules (around 6-8 $\mathrm{mm}$ ) were too small to permit this injection. The evapotranspirated water was collected daily over 5 days by using plastic bags surrounding the leaves, as proposed by Calder et al. ${ }^{[18,19]}$ The samples of collected water were placed directly into $2.5 \mathrm{~mL}$ glass vials and sent to the laboratory for quantification of the isotopic tracer.

\section{Study site on Mayotte Island}

The experiment on whole trees was conducted on Mayotte Island (French Overseas Territory of the Comoros Archipelago, Indian Ocean). On this volcanic island, mangroves have developed along a great part of the bays and small rivers. The study area is located in the south-west of the island, in Chirongi Bay, which has one of the largest mangroves (nearly $4 \mathrm{~km}$ long and up to $0.8 \mathrm{~km}$ wide) (see Fig. 1). The mangrove tree zonation pattern is characterized by four assemblages with a specific dominant species: first a landward Avicennia marina zone, followed by a zone dominated by Ceriops tagal, then a Rhizophora mucronata zone and, finally, a Sonneratia alba zone whose roots are always flooded by lagoon water (see Fig. 2). Rhizophoras and Ceriops cover the greatest area, ${ }^{[23,24]}$ and the water needs of these two species will be studied here. The climate is of the tropical marine type with a mean annual rainfall of around $1500 \mathrm{~mm}$ and a bimodal distribution. Of the total rainfall 80 $\%$ occurs during the wet season from November to April, followed by a cooler dry season from May to October. The mean annual temperature is $25^{\circ} \mathrm{C}$.

We chose three dominant trees $(\mathrm{C} 1, \mathrm{C} 2$ and $\mathrm{C} 3)$ in the Ceriops tagal strata and two in the Rhizophora mucronata strata (R1 and R2). These trees were healthy and displayed typical dendrometric characteristics of the

Table 1. Leaf surface area and water consumption of saplings obtained by lysimetry in the tropical greenhouse. Values correspond to the average of leaf surface area (LSA), of weight of water loss (WL), and of evapotranspiration (EVP) for six saplings per species and treatment: high salinity (HS, 35\%o) and low salinity (LS, 3.5\%o). Values marked with an asterisk show a significant difference at the ${ }^{*} p<0.05,{ }^{* *} p<0.01$, and ${ }^{* * *} p<0.001$ levels for independent groups t-tests

\begin{tabular}{|c|c|c|c|c|c|}
\hline Measurement dates & Saplings & $\begin{array}{l}\text { LSA } \\
\left(\mathrm{cm}^{2}\right)\end{array}$ & $\begin{array}{c}\text { WL } \\
\text { (mL/day) }\end{array}$ & $\begin{array}{c}\mathrm{EVP} \\
\left(\mathrm{mL} / \mathrm{day} / \mathrm{cm}^{2}\right)\end{array}$ & \\
\hline \multirow[t]{2}{*}{25 April, 2008} & $\begin{array}{l}\text { Ceriops HS }(35 \%) \\
\text { Ceriops LS }(3.5 \%)\end{array}$ & $\begin{array}{l}38.8 \pm 8.2 \\
49.1 \pm 19.1\end{array}$ & $\begin{array}{l}1.6 \pm 0.5 \\
2.9 \pm 1.6\end{array}$ & $\begin{array}{l}0.041 \pm 0.012 \\
\mathbf{0 . 0 5 7} \pm \mathbf{0 . 0 1 2}\end{array}$ & $\begin{array}{c}+39.7 \% \\
p=0.048\end{array}$ \\
\hline & $\begin{array}{l}\text { Rhizophora HS (35\%) } \\
\text { Rhizophora LS (3.5\%) }\end{array}$ & $\begin{array}{l}203.4 \pm 81.9 \\
181.8 \pm 38.8\end{array}$ & $\begin{array}{l}11.2 \pm 4.2 \\
14.5 \pm 4.0\end{array}$ & $\begin{array}{l}0.057 \pm 0.005 \\
\mathbf{0 . 0 7 9} \pm \mathbf{0 . 0 0 8}\end{array}$ & $\begin{array}{c}+37.8 \% \\
p=0.0002\end{array}$ \\
\hline \multirow[t]{2}{*}{5 June, 2008} & $\begin{array}{l}\text { Ceriops HS }(35 \%) \\
\text { Ceriops LS }(3.5 \%)\end{array}$ & $\begin{array}{l}49.7 \pm 10.9 \\
61.1 \pm 23.1\end{array}$ & $\begin{array}{l}2.9 \pm 1.1 \\
4.7 \pm 1.4\end{array}$ & $\begin{array}{l}0.057 \pm 0.015 \\
\mathbf{0 . 0 8 0} \pm \mathbf{0 . 0 1 6}\end{array}$ & $\begin{array}{c}+40.2 \% \\
p=0.036\end{array}$ \\
\hline & $\begin{array}{l}\text { Rhizophora HS (35\%o) } \\
\text { Rhizophora LS }(3.5 \% \mathrm{o})\end{array}$ & $\begin{array}{l}243.2 \pm 88.5 \\
273.4 \pm 64.4\end{array}$ & $\begin{array}{l}14.6 \pm 5.1 \\
19.3 \pm 5.0\end{array}$ & $\begin{array}{l}0.061 \pm 0.005 \\
\mathbf{0 . 0 8 2} \pm \mathbf{0 . 0 1 0}\end{array}$ & $\begin{array}{c}+35.0 \% \\
p=0.001\end{array}$ \\
\hline
\end{tabular}




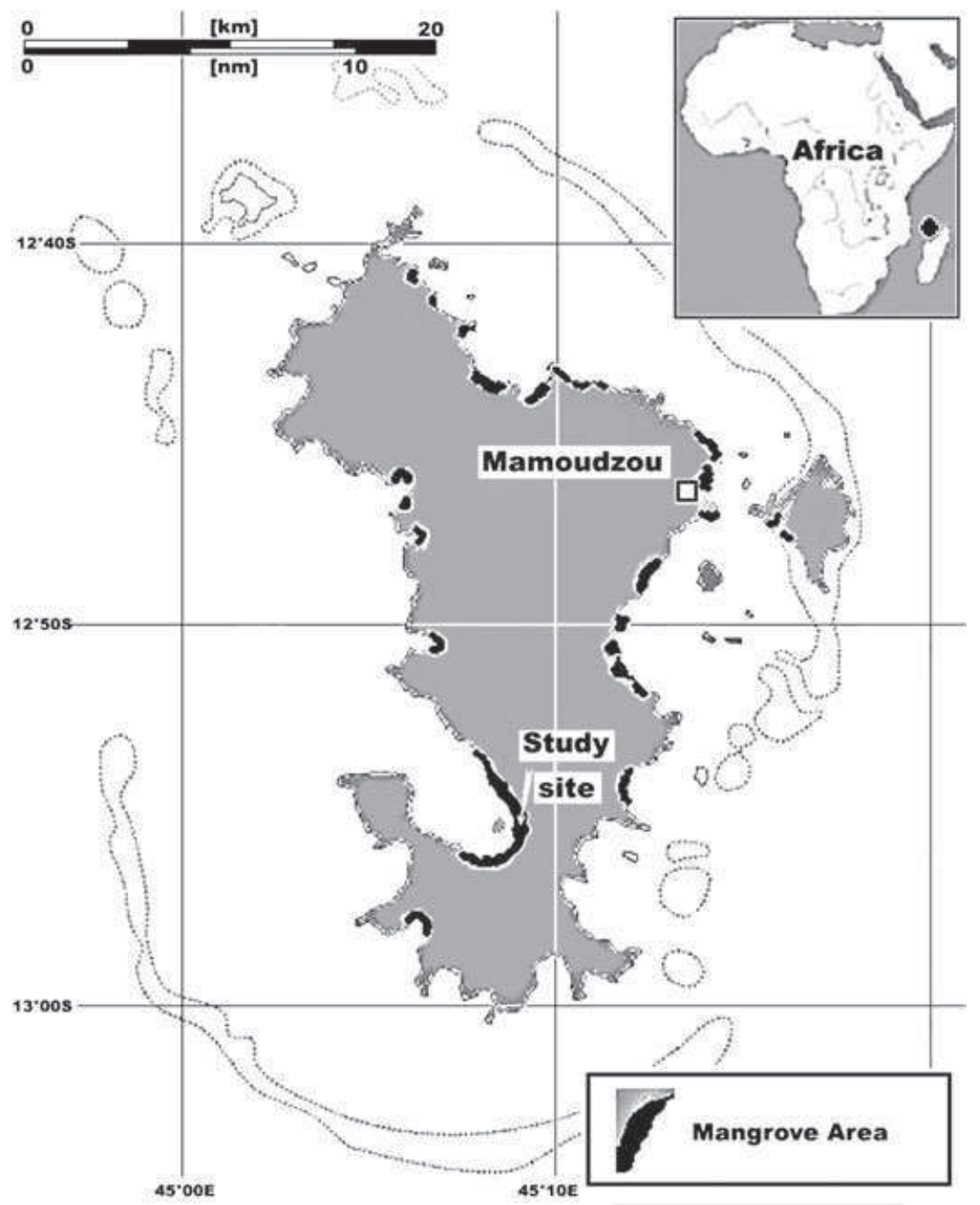

Figure 1. Location of the mangrove forest (black) and the study site in the Chirongui Bay on Mayotte, Comores Islands, Indian Ocean.

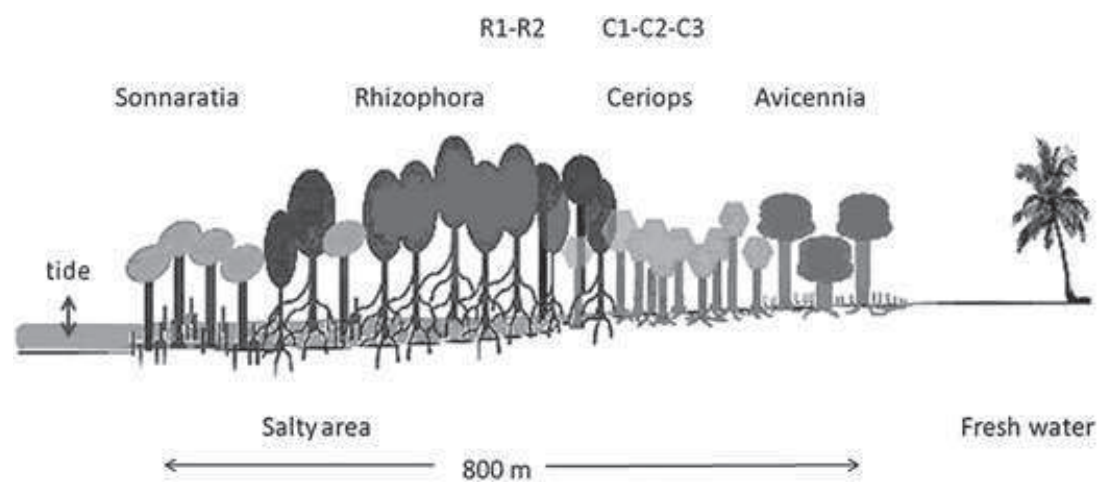

Figure 2. Zonation of the mangrove of Malamani (modified from Herteman ${ }^{[34]}$ ) and location of the sampled trees: R1 and R2 for Rhizophora strata and C1-C3 for the Ceriops strata. 
strata (see Table 1). However, the R. mucronata trees were chosen with morphological characteristics permitting the climbing to reach the crown leaves. Measurements were taken daily over a period of 16 days from 26 March to 11 April, 2008.

\section{Sap flow measurement procedure}

The deuterium tracing method, described by Calder and colleagues, ${ }^{[17-19]}$ involves the injection of a known mass of deuterium oxide $\left(\mathrm{D}_{2} \mathrm{O}\right)$ into the base of the tree. The total mass of tracer $\left(\mathrm{D}_{2} \mathrm{O}, 99.85 \%\right.$ minimum purity) administered into each of the trunks varied from 2.5 to $5.0 \mathrm{~mL}$ according to the height of each tree (Table 2). These quantities were calculated as described in the literature $\mathrm{e}^{[20,21]}$ and following our prior experiments on Rhizophora saplings in the Toulouse greenhouse.

On 27 March 2008 (at the end of the rainy season), the $\mathrm{D}_{2} \mathrm{O}$ was injected into the transpiration stream through holes spaced at regular intervals around the circumference of the base of the trunk. For the Ceriops, the injections were made just over the tree buttress, $30-40 \mathrm{~cm}$ above ground, and for the Rhizophoras above the last root stilt, $60-100 \mathrm{~cm}$ above ground, high enough to be in the main ascendant flux and to avoid the risk of loss to the roots. However, we took care to carry out the injections far enough below the base of the branches to allow the complete mixing of tracer into the flux and a compromise had to be found with the first condition. ${ }^{[22]}$ To reach the sapwood of trees, a $6 \mathrm{~mm}$ wide hole was drilled 3 to $5 \mathrm{~cm}$ downward at an angle of $30^{\circ}$ from the horizontal. For the Rhizophoras, $10 \mathrm{~mm}$ of bark was first removed with a sharp wood chisel. The required tracer volume was then injected with a syringe and the holes closed with putty.

The number of bags was adapted to the size of the tree (from 3 to 5) and each bag was placed at a different height within the canopy to reflect the heterogeneity of the evapotranspiration. Over a period of 13 to 15 days, the condensed water was sampled at daily intervals with replacement of the bags. The sampling started 1 day prior to the $\mathrm{D}_{2} \mathrm{O}$ injection in order to have data for the blank control. Every day, up to $1.5 \mathrm{~mL}$ of water accumulated in the bags. However, only fractions of $0.5 \mathrm{~mL}$ were taken in each one, mixed into a mean daily sample and transferred into $2.5 \mathrm{~mL}$ glass vials according to the protocol of Calder et al. ${ }^{[19]}$ and adapted by Marc and Robinson. ${ }^{[20]}$ Using the totality of the $\mathrm{D}_{2} \mathrm{O}$ recovered over the sampling period, we can apply the mass balance equation proposed by Calder et al.:[17-19]

$$
M=F \int_{t_{0}}^{t_{1}} C \mathrm{~d} t
$$

knowing that the total amount of tracer administered, $\mathbf{M}(\mathrm{g})$, is related to the sap flow $\mathbf{F}$ (L/day) by the mass conservation principle, where $\mathbf{C}$ is the concentration of deuterium in the evapotranspired water $(\mathrm{g} / \mathrm{L})$ and $\mathbf{t} \mathbf{0}$ and $\mathbf{t} \mathbf{1}$ are the first and the last time increments in which tracer is present (days).

\section{Deuterium measurement}

The isotopic analyses were carried out by continuous flow isotope ratio mass spectrometry on an ANCA-GSL combined elemental analyzer and gas purification module linked to a Geo20-20 isotope ratio mass spectrometer (both from Europa Scientific, Crewe, UK) following headspace equilibration (Isoanalytical Laboratory, Crewe, UK). The mass spectrometer is fitted with a long spur flight tube to allow separation of hydrogen from helium. Three working laboratory standards for enriched water were used: IA-R054, IA-R055 and IAR056. All are traceable to VSMOW2/V-SLAP2. The results are reported in delta notation in units of permil on the VSMOW/SLAP scale for deuterium with V-SMOW2: new Vienna Standard Mean Ocean Water and V-SLAP2: new Vienna Standard Light Antarctic Precipitation (both from IAEA, Vienna, Austria).

\section{Statistical tests}

After verification of the normal distribution of our data, Student' t-test was used with a $p$ value $<0.05$. For the non-normal distribution, the Mann-Whitney's U-test was chosen with a $p$ value $<0.05$. These statistical tests were performed using Statistica software (version 8.0; Tulsa, OK, USA) and the program R (version 2.12.0).

\section{RESULTS}

\section{Growth and water use of saplings in response to salinity}

Table 1 shows the main results for height growth rates, leaf surface areas and evapotranspiration (EVP) of Rhizophora and Ceriops saplings, placed for 3 and 4 months in the original simulator of tides in the tropical greenhouse.

Table 2. Trees characteristics in Mayotte, amount of injected of deuterium tracer injection and calculated sap fluxes. With $\mathrm{H}$ : trees height $(\mathrm{cm}), \mathrm{DBH}$ : tree diameter at breast height, LSA: estimated leaf surface area of the tree, $\mathrm{V} \mathrm{D}_{2} \mathrm{O}:$ volume of $\mathrm{D}_{2} \mathrm{O}$ injected, $\mathrm{H}$ inj.: height of the injection in the tree $(\mathrm{cm}), \mathrm{D}$ : duration of the tracer passage (days)

\begin{tabular}{|c|c|c|c|c|c|c|c|c|c|c|}
\hline & $\begin{array}{c}\mathrm{H} \\
(\mathrm{cm})\end{array}$ & $\begin{array}{l}\mathrm{DBH} \\
(\mathrm{cm})\end{array}$ & $\begin{array}{l}\text { LSA } \\
\left(\mathrm{m}^{2}\right)\end{array}$ & $\begin{array}{l}\mathrm{V} \mathrm{D}_{2} \mathrm{O} \\
(\mathrm{mL})\end{array}$ & $\begin{array}{l}\mathrm{H} \text { inj. } \\
(\mathrm{cm})\end{array}$ & $\begin{array}{c}\mathrm{D} \\
\text { (days) }\end{array}$ & $\begin{array}{c}\text { Mean } \\
\text { sapflow (L/day) }\end{array}$ & $\begin{array}{l}\text { Mean sapflow } \\
(\mathrm{L} / \text { day/cm) }\end{array}$ & $\begin{array}{l}\text { Sap velocity } \\
\text { (m/day) }\end{array}$ & $\begin{array}{r}\text { Residence } \\
\text { time (days) }\end{array}$ \\
\hline Ceriops 1 & 310 & 6,5 & 2.8 & 2,5 & 30 & 16 & 7.5 & 1.15 & 1.27 & $?$ \\
\hline Ceriops 2 & 250 & 8 & 4.4 & 3 & 20 & 14 & 10 & 1.25 & 0.96 & $?$ \\
\hline Ceriops 3 & 300 & 8 & 4.9 & 3 & 30 & 17 & 8.3 & 1.04 & 1.29 & 2.2 \\
\hline Mean & & & & & & & & $1.15 \pm 0.11$ & $1,17 \pm 0.19$ & \\
\hline Rhizo. 1 & 750 & 22 & _ & 5 & 100 & 16 & 17.6 & 0.8 & 2.03 & 1.5 \\
\hline Rhizo. 2 & 500 & 13 & - & 4 & 100 & 20 & 10.7 & 0.83 & 1.39 & 2.1 \\
\hline Mean & & & & & & & & $0.82 \pm 0.02$ & $1.71 \pm 0.45$ & \\
\hline
\end{tabular}


The effective evapotranspiration (EVP) was calculated by dividing the leaf surface area by the difference in weight obtained by lysimetry after 1 day. Measurements were carried out three times: 2, 3 and 4 months after the placement of the saplings in their respective salinities. The rates of EVP are coherent and of the same order of magnitude for the two species, varying from 0.05 to $0.08 \mathrm{~mL} /$ day $/ \mathrm{cm}^{2}$. As expected, the water absorption was much lower for the saplings in seawater conditions (salinity of 35\%o) for both Ceriops and Rhizophora. However, the differences in water consumption of the saplings between the two treatments were only significant from the second time of measurement, after a 3 month adaptation of the saplings to the ambient salinity. We chose to represent only the values of the two last measurements in Table 1. The water uptake in the near freshwater conditions $(3.5 \%$ ) compared with that of seawater then showed a similar increase of about $39 \%$ for both species. No significant difference is detected for the height of saplings and the leaf surface areas between the treatments.

\section{Deuterated water injection into Rhizophora saplings}

The injection of heavy water was only performed into the eight larger Rhizophora saplings, the Ceriops stems being too thin to absorb the tracer volume. However,, in the Rhizophora saplings, it was difficult to input exactly $0.5 \mathrm{~mL}$ of $\mathrm{D}_{2} \mathrm{O}$. Nevertheless, 0.2 to $0.5 \mathrm{~mL}$ of deuterated water was collected in plastic bags enclosing the leaves, and the $\mathrm{D}_{2} \mathrm{O}$ could be detected after 3 days for both salinity conditions. The peaks of tracer had still not been reached after 5 days which clearly indicated the need to sample over at least 12 days for the bigger trees on the field site. However, since nearly all the leaves of saplings were enclosed in plastic bags for sampling, the measures of water uptake are no longer quantitative due to these confining conditions.

\section{Sap flow and sap velocity of Ceriops tagal and Rhizophora mucronata on Mayotte Island}

Figures 3 and 4 show the time-course curves of tracer in the sap flux for the five trees. In this case, the technique is quantitative because the number of leaves enclosed in plastic bags

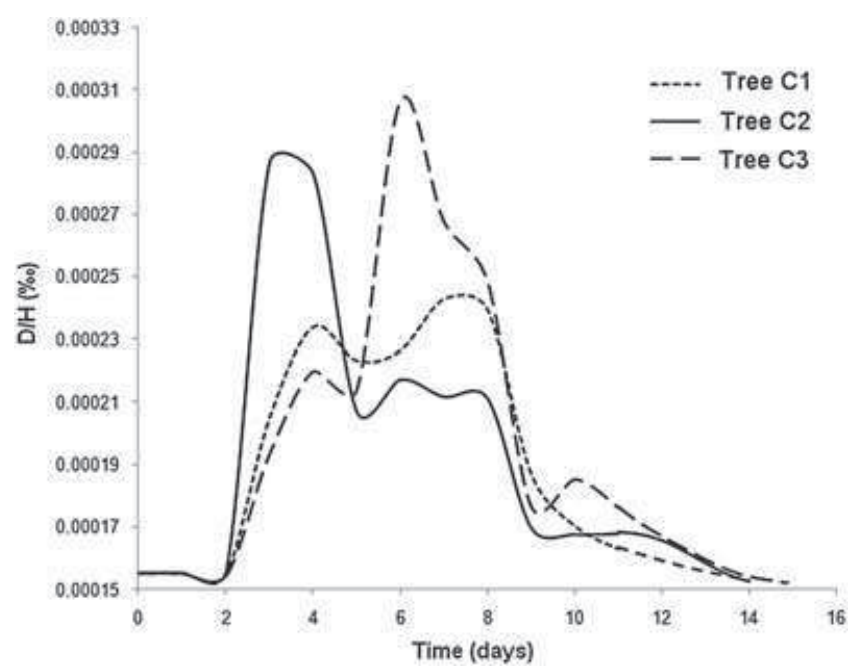

Figure 3. Time course of D atom $\%$ values of water extracted from the leaf canopy for Ceriops trees.

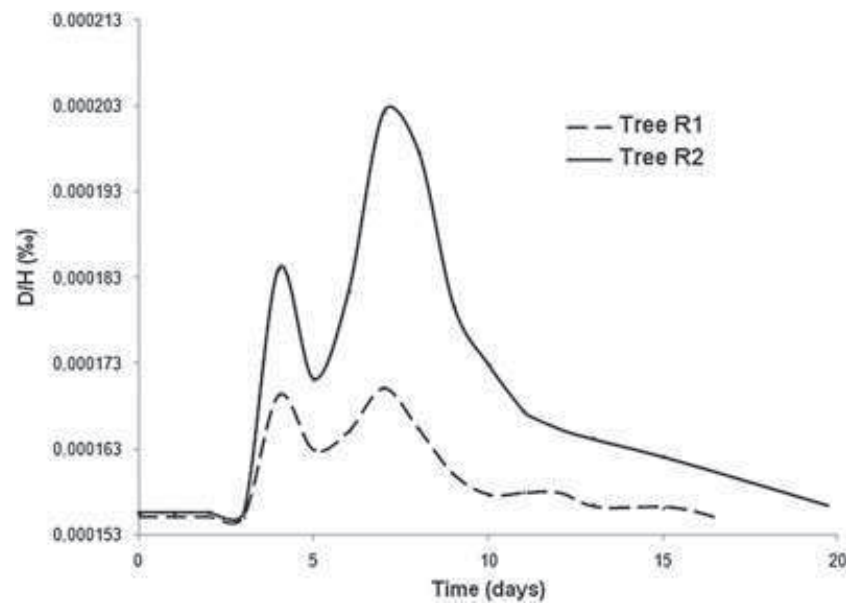

Figure 4. Time course of D atom \% values of water extracted from the leaf canopy for Rhizophora trees.

is small relative to the total number of leaves. The tracer was detected 3 days after injection in the Ceriops trees and after 4 days in the Rhizophora trees. The maximum amount of tracer was observed between day 3 and day 8 for each of the trees. The drops in tracer concentration around days 5-6 and to a lesser extent on days 9-10 were due to heavy rainfall on the previous days, April being the last month of the wet season. These events significantly increased the water consumption of the trees, diluting the tracer in the sap flow and giving an atypical form to the tracer time-course curves. The experiment was stopped 13 days after injection for the smaller trees and after 15 days for the larger trees.

However, more than 15 days were needed to return to the baseline, and for the C 3 and R2 curves, an extrapolation calculation was carried out to integrate the whole curve above the pre-injection levels and thus estimate the sap flow. The three Ceriops trees display similar water consumption of $8.6 \pm 1.3 \mathrm{~L} /$ day (see Table 2). The two larger Rhizophora trees show higher water need, ranging from 11 to $18 \mathrm{~L} /$ day. This water consumption was also weighted by the trees' diameter at breadth eight as the sapwood area could not be determined. Similar values obtained from each species, $1.15 \pm 0.11 \mathrm{~L} /$ day per $\mathrm{cm}$ of trunk diameter for Ceriops and $0.82 \pm 0.02 \mathrm{~L} /$ day per $\mathrm{cm}$ of trunk diameter for Rhizophora, demonstrate the consistency of measurements and that the tracer is well dispersed throughout the sap wood volume.

The sap (tracer) velocity can be calculated by dividing the estimated path length from the injection point to the sampling point by the time required for the tracer to reach around $10 \%$ of its maximum concentration above baseline levels. ${ }^{[21]}$ This calculation is given in Table 2. The values range from 1 to $1.3 \mathrm{~m} /$ day for the Ceriops trees, and from 1.4 to $2 \mathrm{~m} /$ day for the Rhizophora trees. It is clear that it is the smaller tree (see C2 in Table 2), and thus the one which displays the shortest sap path length, which nearly reached its maximum, before the arrival of the heavy rain on day 5 . The tracer residence time is obtained by calculating the time required for the tracer concentration to drop to one-half of its maximum value. Due to the rainfall events, the time-course curves (Figs. 3 and 4) do not follow a typical Gaussian profile. Residence time calculations are thus not feasible for trees C1 and C2. Nevertheless, for the other curves, the residence time can be estimated at around 2 days. 


\section{Uncertainty analysis}

Extrapolation of water consumption of trees at stand level

From the data of a previous study of the vegetation structure of Malamani mangrove, ${ }^{[25]}$ an extrapolation of tree water consumption at stand level was carried out (Table 3). The studied mangrove area extends over $675 \mathrm{~m}^{2}$ and each stratum has a relatively homogeneous structure. According to these estimates, the water consumption on the stand would be approximately $11 \mathrm{~m}^{3}$ /day in the Ceriops tagal stratum, and $5 \mathrm{~m}^{3}$ /day in the Rhizophora mucronata stratum. At the level of one hectare, water consumption would then be $1.7^{*} 10^{5} \mathrm{~m}^{3} /$ day in the C. tagal stratum, and $7.6^{*} 10^{4} \mathrm{~m}^{3} /$ day in the Rhizophora mucronata stratum.

\section{DISCUSSION}

The two studied mangrove trees, C. tagal and R. mucronata, belong to the same Rhizophora family, but have different strategies to overcome high salinity conditions. The former adjusts its osmotic potential according to the external conditions by storing large quantities of chloride and sodium ions, i.e. non-secretor and osmo-conformer type. ${ }^{[25]}$ The latter possesses an ultra-filtration system able to block the entry of salt at root level and this allows the plant to take up less salty water, i.e. non-secretor and salt-excluder type. ${ }^{[26]}$ Both C. tagal and R. mucronata do not present a change in color between the sapwood and the hardwood. Thus, the sapwood could not be determined. As this parameter was not available, the tree diameter was used to compare the tree water uptake. When the volume of water taken up is divided by the tree diameter (see Table 2), we see that the Ceriops trees differ in their ability to pump the salty water from the Rhizophora trees, with $1.15 \pm 0.11$ and $0.82 \pm 0.02 \mathrm{~L} /$ day $/ \mathrm{cm}$, respectively. These measurements were made at the end of March, where the hydrological conditions indicate the ending wet season with its surface desalinization. This means that during the dry season, these water uptake values will decrease. In our greenhouse experiments with the same species, we obtained a decrease of $39 \%$ when passing from low salinity conditions to high ones. In French Guyana, we measured the sap flux

Table 3. Tentative upscaling calculation for daily water use of trees at the stand level

\begin{tabular}{|c|c|c|c|c|c|c|}
\hline & $\begin{array}{l}\text { Relative tree } \\
\text { stand } \\
\text { composition }\end{array}$ & $\begin{array}{l}\text { Stand density } \\
\text { (irrespective of } \\
\text { species) (tree } / \mathrm{m}^{2} \text { ) }\end{array}$ & $\begin{array}{l}\text { Mean tree } \\
\text { diameter } \\
(\mathrm{cm})\end{array}$ & $\begin{array}{l}\text { Mean tree } \\
\text { elevation } \\
(\mathrm{m})\end{array}$ & $\begin{array}{c}\text { Calculation of tree } \\
\text { water use per stand } \\
\text { area (L/day/stand } \\
\text { area) }\end{array}$ & $\begin{array}{c}\text { Tree water use } \\
\text { per hectare } \\
(\mathrm{kL} / \text { day } / \mathrm{ha})\end{array}$ \\
\hline Ceriops tagal stratum & $\begin{array}{c}\mathbf{9 0 \%} \text { C. tagal } \\
9 \% \text { R. mucronata }\end{array}$ & 6.9 & $\begin{array}{l}2.2 \\
4.8\end{array}$ & $\begin{array}{l}2.6 \\
-\end{array}$ & 11250 & 167 \\
\hline $\begin{array}{l}\text { Rhizophora mucronata } \\
\text { stratum }\end{array}$ & $\begin{array}{c}79 \% \text { R. mucronata } \\
16 \% \text { C. tagal }\end{array}$ & 0.79 & $\begin{array}{r}16.1 \\
4.1\end{array}$ & $\begin{array}{l}7.1 \\
2.6\end{array}$ & 5156 & 76 \\
\hline
\end{tabular}

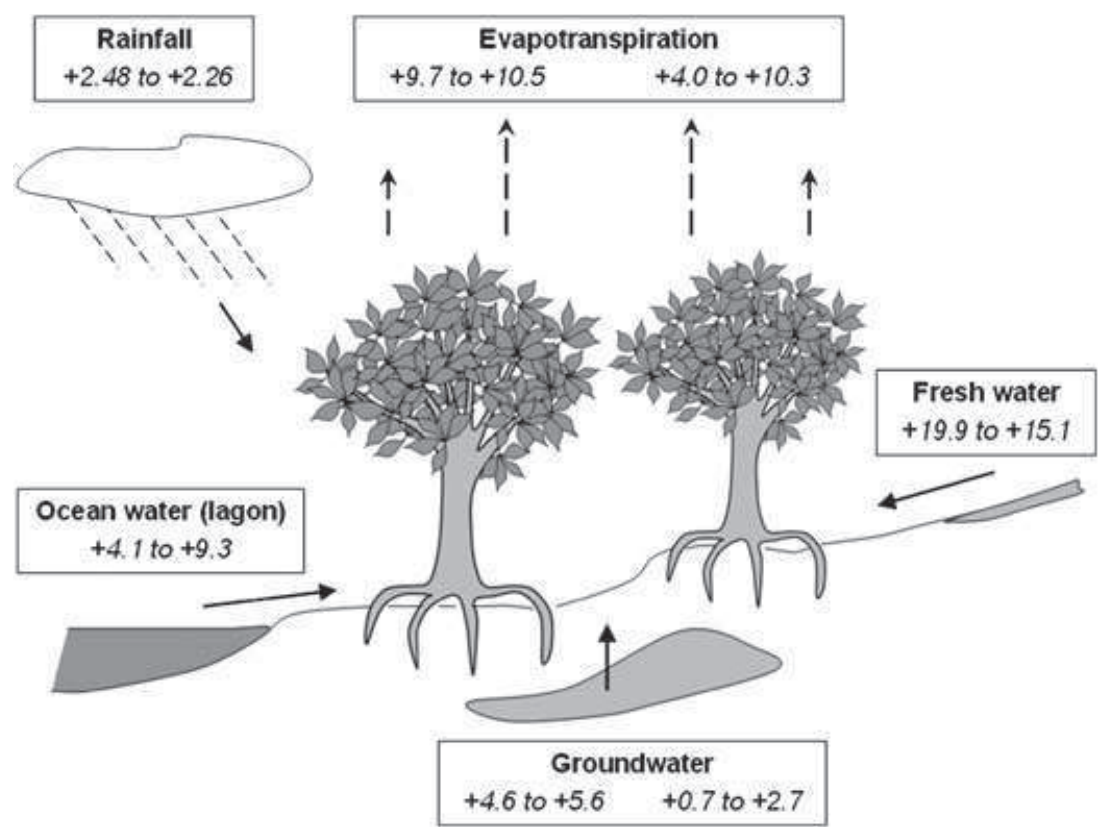

Figure 5. Synoptic figure of the water circulation and the $\delta \mathrm{D}$ values of the different water pools, in relation the obtained evaporated water before the $\mathrm{D}_{2} \mathrm{O}$ injection. 
of Avicennia germinans using heat sensors. ${ }^{[1]}$ In that back mangrove we obtained a mean value of $1.36 \pm 0.23 \mathrm{~L} /$ day $/ \mathrm{cm}$ for the wet season, i.e. about the same order of magnitude as obtained in the present study. For the dry season this mean value dropped to $0.69 \pm 0.33 \mathrm{~L} /$ day $/ \mathrm{cm}$, which corresponds to a decrease of $48.5 \%$. The $A$. germinans displays a large sapwood (many $\mathrm{cm}$ wide), ${ }^{[1]}$ and it is a secretor type, the salt being excreted by the leaves.

Salinity has a major impact on water uptake and mangrove development. ${ }^{[27-29]}$ Many studies have shown that high salinity conditions diminish the growth of mangrove trees and their leaf surface. ${ }^{[25,30-32]}$ By contrast, the growth is enhanced and the vegetation is more luxuriant when the salinity conditions are lower. ${ }^{[28,30]}$ The example of our own saplings' growth after 1 year in the tropical greenhouse shows that the difference in growth between the plants from the low and high salinity tanks decreases, until it is no longer significant. The samplings from the saltiest tank slowly increased in height to become similar to the ones in the less salty tank. It seems that the saplings were more influenced by changes in salinity than by the salinity itself, as has been reported previously. ${ }^{[25,30]}$

The calculations of the sap velocity and residence time are only indicative, as the time course was interrupted by cloudy days. The mean sap velocities obtained, $1.2 \pm 0.2 \mathrm{~m} /$ day for the three Ceriops trees and $1.7 \pm 0.4 \mathrm{~m} /$ day for the two Rhizophora trees, are relatively low values certainly due to the high osmotic work in these high salinity condition. Typical tropical trees display values ranging from 5 to $26 \mathrm{~m} /$ day and, for temperate trees, values range from 3 to $5 \mathrm{~m}$ day. ${ }^{[21,33]}$ In general, the sap velocity decreases with the sapwood capacitance. The value obtained for the residence time - around 2 days - is also more similar to temperate trees that to tropical trees. ${ }^{[21]}$

Figure 5 summarizes the water circulation and the $\delta \mathrm{D}$ values of the different water pools around the studied trees. The range of the values corresponds to the extreme values obtained ( 2 to 3 sampling). For the evaporated water, it is the water obtained in the plastic bag before the $\mathrm{D}_{2} \mathrm{O}$ injection, i.e. the blank values. These values show that during the time of the tracing experiment, both types of mangrove trees were mainly taking the water coming from the ocean with positive $\delta \mathrm{D}$ values. There is slight mixing of fresh water for the ground water under the Ceriops which is also seen in the lower values found for two Ceriops trees $(\delta \mathrm{D}=+4.0$ and 7.6).

\section{CONCLUSIONS}

The deuterium tracing technique together with the collection of the evaporated water using plastic bags on canopy leaves turns out to be an efficient method for use in very saline conditions such as for mangrove trees. These severe conditions cause low tracer velocity but typical residence time. While the sap flux values are not very different from those found in Guyana (respectively, 1.15 and $1.36 \mathrm{~L} /$ day/cm), as the trees are much smaller in Mayotte, the largest Rhizophora (diameter $25 \mathrm{~cm}$ ) could take up only around $29 \mathrm{~L} /$ day, whereas in Guyana a large Avicennia (diameter $52 \mathrm{~cm}$ ) can take up more than $70 \mathrm{~L} /$ day. The trees in Mayotte come from the poorest substrate, and this may explain their lower growth rate.

\section{Acknowledgements}

We would like to thank V. Marc (University of Avignon, France) and C. Bellanger (www. Iso-analytical.com, UK) for their advice about the deuterium tracing, D. Mazeau and T. Cambouvile (University of Toulouse) for the access to the botanical garden of Toulouse and the use of the tropical greenhouse, D. Boutaud (Ecolab Toulouse) for the construction of the electric panel for the tide system, M. Souriat (Ecolab Toulouse) for the long sapling monitoring, and $\mathrm{M}$. Herteman and F. Fromard (Ecolab Toulouse) for the logistical cooperation in Mayotte. This research was funded by the PIR CNRS program 'Ingénierie Ecologique 2007'. Thanks to Victoria McBride for correcting the English.

\section{REFERENCES}

[1] E. Muller, L. Lambs, F. Fromard. Variations in water use by a mature mangrove of Avicennia germinans, French Guiana. Ann. For. Sci. 2009, 66, 803.

[2] P. B. Tomlinson. The Botany of Mangroves, Cambridge University Press, Cambridge, 1986.

[3] P. Becker, A. Asmat, J. Mohamad, M. Moksin, M. T. Tyree. Sap flow of mangrove trees are not usually low. Trees 1997, $11,432$.

[4] M. A. Sobrado, S. L. Ewe. Ecophysiological characteristics of Avicennia germinans and Laguncularia racemosa coexisting in a scrub mangrove forest at the Indian River Lagoon, Florida. Trees 2006, 20, 679 .

[5] F. Pannier. Mangrove physiology: water relations, in The Mangrove Ecosystem: Research Methods, (Eds: S. C. Snedaker, J. G. Snedaker), Unesco, Paris, 1984, p. 208.

[6] M. C. Ball. Ecophysiology of mangroves. Trees 1988, 2, 129.

[7] M. C. Ball. Comparative ecophysiology of mangrove forest and tropical lowland moist rainforest, in Tropical Forest Plant Ecophysiology, (Eds: S. S. Mulkey, R. L. Chazdon, A. P. Smith), Chapman \& Hall, New York, 1996, p. 461.

[8] P. Saenger. Mangrove Ecology, Silviculture and Conservation, Kluwer Academic Publishers, Dordrecht, 2002, p. 372.

[9] P. F. Scholander. How mangroves desalinate water. Physiologia Plantarum. Plant Physiol. 1968, 21, 251.

[10] M. Popp. Salt resistance in herbaceous halophytes and mangroves. Prog. Bot. 1995, 56, 416.

[11] L. S. L. Sternberg, P. K. Swart. Utilization of freshwater and ocean water by coastal plants of southern. Ecology 1987, 68, 1898.

[12] F. Rada, G. Goldstein, A. Orozco, M. Montilla, O. Zabala, A. Azocar. Osmotic and turgor relations of three mangrove ecosystem species. Aust. J. Plant Physiol. 1989, 16, 477.

[13] E. Wolanski, P. Ridd. Tidal mixing and trapping in mangrove swamps. Estuar. Coast. Shelf. Sci. 1986, 23, 759.

[14] G. Lin, L. S. L. Sternberg. Utilization of surface water by red mangrove (Rhizophora mangle L.) - an isotopic study. Bull. Mar. Sci. 1994, 54, 94.

[15] P. Hogarth. The Biology of Mangroves, Oxford University Press, New York, 1999, p. 228.

[16] J. A. C. Smith, M. Popp, U. Luttge, W. J. Cram, M. Diaz, H. Griffiths, H. S. J. Lee, E. Medina, C. Schafer, K. H. Stimmel, B. Thonke. Ecophysiology of xerophytic and halophytic vegetation of a coastal alluvial plain in northern Venezuela. New Phytol. 1989, 111, 293.

[17] I. R. Calder, M. N. Narayanswamy, N. V Srinivasalu, W. G. Darling, A. J. Lardner. Investigation into the use of 
deuterium as a tracer for measuring transpiration from eucalypts. J. Hydrol. 1986, 84, 345.

[18] I. R. Calder, G. S. Kariyappa, N. V. Srinivasalu, K. V. Srinivasa Murty. Deuterium tracing for the estimation of transpiration from trees. Part 1. Field calibration. J. Hydrol. 1992, 130, 17.

[19] I. R. Calder. Deuterium tracing for the estimation of transpiration from trees. Part 2. Estimation of transpiration rates and transpiration parameters using a time-averaged deuterium tracing method. J. Hydrol. 1992, 130, 27.

[20] V. Marc, M. Robinson. Application of the deuterium tracing method for the estimation of tree sap flow and stand transpiration of a beech forest (Fagus silvatica L.) in a mountainous Mediterranean region. J. Hydrol. 2004, 285, 248.

[21] F. C. Meinzer, J. R. Brooks, J.-C. Domec, B. L. Gartner, J. M. Warren, D. R. Woodruf, K. Bible, D. C. Shaw. Dynamics of water transport and storage in conifers studied with deuterium and heat tracing techniques. Plant Cell Environ. 2006, 29, 105.

[22] L. Schwendenmann, D. Dierick, M. Köhler, D. Hölscher. Can deuterium tracing be used for reliably estimating water use of tropical trees and bamboo? Tree Physiol. 2010, 30, 886.

[23] F. Fromard, Les mangroves de Mayotte: Analyse écologique et propositions de restauration. Rapport. Société Espaces, Sada et Laboratoire d'Ecologie Terrestre-CNRS, Toulouse, 2000.

[24] F. Fromard, A. Bousquet-Melou. Les mangroves de Mayotte: Rapport bibliographiques. Société Espaces, Sada et Laboratoire d'Ecologie Terrestre-CNRS, Toulouse, 2000.
[25] I. Aziz, M. A. Khan. Experimental assessment of salinity tolerance of Ceriops tagal seedlings and saplings from the Indus delta, Pakistan. Aquat. Bot. 2001, 70, 259.

[26] R. Lawton, A. Todd, D. K. Naidoo. Preliminary investigations into the sdtructure of the roots of the mangroves, Avicennia marina and Bruguiera gymnorrhiza, in relation to ion uptake. New Phytol. 1981, 88, 713.

[27] C. Paliyavuth, B. Clough, P. Patanaponpaiboon. Salt uptake and shoot water relations in mangroves. Aquat. Bot. 2004, 78,349 .

[28] C. E. Lovelock, M. C. Ball, I. C. Feller, B. M. J. Engelbrecht, M. M. Ewe. Variation in hydraulic conductivity of mangroves: Influence of species, salinity, and nitrogen and phosphorus availability. Physiol. Plant. 2006, 127, 457.

[29] L. Lopez-Hoffman, N. P. R. Anten, M. Martinez-Ramos, D. D. Ackerly. Salinity and light interactively affect Neotropical mangrove seedlings at the leaf and whole plant levels. Oecologia 2007, 150, 545.

[30] K. Kathiresan, B. L. Bingham. Biology of mangroves and mangrove ecosystems. Adv. Mar. Biol. 2001, 40, 81.

[31] B. F. Clough. Growth, salt balance of the mangroves, Avicennia marina (Forsk.) Vierh. and Rhizophora stylosa Griff., in relation to salinity. Aust. J. Plant Physiol. 1984, 11, 419.

[32] M. D. Burchett, C. J. Clarke, C. D. Field, A. Pulkownik. Growth and respiration in two mangrove species at a range of salinities. Physiol. Plant. 1989, 75, 299.

[33] F. C. Meinzer, S. A. James, G. Goldstein, D. Woodruff. Whole-tree water transport scale with sapwood capacitance in tropical forest canopy trees. Plant Cell Environ. 2003, 26, 1147.

[34] M. Herteman. PhD thesis, Toulouse University, France, 2010. 